\title{
Cerebral Tolerance of Hypoxia in Growth- Retarded and Appropriately Grown Newborn Guinea Pigs
}

\author{
MAGNUS THORDSTEIN AND INGEMAR KJELLMER \\ Departments of Physiology and Pediatrics I, Gothenburg University, Göteborg, Sweden
}

\begin{abstract}
To elucidate if there is a reduced perinatal tolerance of hypoxia in growth retardation and approach its pathophysiologic background, newborn guinea pigs of different weights were subjected to standardized hypoxia. Intrauterine growth retardation was induced through uterine artery ligation. After spontaneous delivery experiments were performed within 2 days. After stabilization, hypoxia of stepwise increased severity was instituted. Blood gases, metabolic, cardiovascular, and neurophysiologic [somatosensory-evoked potentials (SEP)] parameters were monitored. A control series in which equally large blood samples were taken at the same intervals was performed. The animals were grouped according to birth weight: $\geq 101 \mathrm{~g}$ $(n=10,12), 71-100 \mathrm{~g}(n=11,10)$, and $\leq 70 \mathrm{~g}(n=8,3)$ (hypoxic and control series, respectively). Basal SEP latencies did not differ between the groups. Under hypoxia, both the amplitude of the SEP and the time to complete loss of the SEP was reduced in proportion to the degree of growth retardation. The differences between all groups were significant. The animals in the control series did not change their SEP performance significantly. Slight differences in metabolic and cardiovascular parameters between the groups were found not likely to explain the differences in SEP performance. Therefore, it is concluded that a reduced cerebral tolerance of hypoxia prevails in growthretarded newborn guinea pigs and that this is related to changes in the brain itself. It is also concluded that a relationship exists between the degree of growth retardation and that of reduced cerebral hypoxia tolerance. (Pediatr Res 24: 633-638, 1988)
\end{abstract}

\section{Abbreviations}

SEP, somatosensory evoked potentials

IUGR, intrauterine growth retardation

SGA, small for gestational age

$\mathrm{Sa}_{2}$, oxygen saturation of arterial blood

$\mathrm{Fio}_{2}$, percentage of oxygen in inspired gas mixture

AGA, appropriate for gestational age

sc, subcutaneous

im, intramuscular

ip, intraperitoneal

ia, intraarterial

PE, polyethylene

Received December 31, 1987; accepted July 25, 1988

Correspondence and reprint requests Magnus Thordstein, M.D., Division of Perinatal Physiology, Department of Physiology, Gothenburg University, P.O. Box 33031, S-400 33 Göteborg, Sweden.

Supported by the Medical Research Council (02591), the "Expressen" Prenatal Foundation, the "Samariten" Foundation, Frimurare Barnhusdirektionen, Gothenburg, and the Medical Faculty, Gothenburg University.
$\mathrm{Pao}_{2}$, oxygen tension of arterial blood $\mathrm{CMRO}_{2}$, cerebral metabolic rate of oxygen

IUGR resulting in neonates who are SGA remains a major problem in modern perinatal care. Fetuses and neonates who are SGA are overrepresented in clinical materials of children with neurodevelopmental handicaps (1-5) and have a several-fold increased risk of perinatal asphyxia $(6,7)$ compared to fetuses and neonates who are AGA. It is uncertain if there is also a reduced tolerance of asphyxia in SGA individuals, the underlying pathophysiologic background of which is obscure. Possible explanations are disturbed metabolic $(8,9)$ or cardiovascular $(10)$ function. Alterations indicating a change in central nervous function have also been noted, suggesting that the reason might reside in the brain itself $(11-15)$.

In countries where malnutrition is uncommon, the majority of IUGR cases is caused by various conditions leading to placental vascular insufficiency with impaired exchange of gases and nutrients over the placenta (16). The aim of this study was to monitor metabolic, cardiovascular, and cerebral function under standardized, progressive hypoxia in newborn guinea pigs with different degrees of IUGR, produced by placental vascular insufficiency. This would make it possible to investigate if there is a reduced perinatal tolerance of hypoxia in growth retarded individuals and if so, approach its pathophysiologic background.

\section{MATERIALS AND METHODS}

Animal handling. A total of 54 offspring from 35 does of the Dunkin-Hartley guinea pig strain were used. Two females and one male were housed together in plastic cages and allowed free access to food (hay and standard pellets; Ewos, Södertälje, Sweden) and water (with ascorbic acid added). Environmental factors were controlled; humidity $(40 \%)$, temperature $\left(21^{\circ} \mathrm{C}\right)$, and light (12 h light-darkness cycles).

Date of mating day (day 0 ) was determined by daily inspection of the vaginal membrane (17). At days 30-32 (full gestation at 66-68) ligation of one or both uterine arteries was performed (18). The does were anesthetized with ketamine and xylazine (30 $\mathrm{mg} \mathrm{sc}$ and $2 \mathrm{mg}$ im, respectively), preceded by atropine $(0.05 \mathrm{mg}$ sc) (19). Under aseptic conditions and temperature control (rectal temperature $37-38^{\circ} \mathrm{C}$ ) a $2-3 \mathrm{~cm}$ lower abdominal midline incision was made and the ligation was performed. Operation time was 15-25 min and the animals recovered, under temperature control, within 2-3 h. After spontaneous delivery at term the neonates were weighed in the morning (when born during the night) or in the evening (when born during the day).

Experimental procedures. Experiments were performed within 2 days after birth. Anesthesia was induced by ketamine $(5 \mathrm{mg} /$ 
$100 \mathrm{~g}$ ip). A tracheal cannula was inserted and connected to a pressure controlled small animal ventilator set to a frequency of $95 / \mathrm{min}$ and an insufflation pressure of $10-20 \mathrm{~cm} \mathrm{H}_{2} \mathrm{O}$. A gas mixture of oxygen and nitrous oxide $40 / 60$ or $50 / 50$ was supplied. Rectal temperature was kept at $37^{\circ} \mathrm{C}$ using a heating lamp. A PE catheter was placed in the left axial artery (PE 10, inner diameter $0.28 \mathrm{~mm}$ connected to PE 90 , inner diameter 0.86 $\mathrm{mm})$. Heparin sodium (500 IE) and alcuronium chloride $(0.05$ $\mathrm{mg}$ ) were administered ia. Throughout the experiment recordings were made on a Grass polygraph no. 7 (Grass Instrument Co., Quincy, MA); ECG (via electrodes placed subcutaneously on forelegs and left hindleg), arterial blood pressure, and heart rate (Statham Gould, A. Gould Inc. Company, Hato Rey, Puerto Rico, pressure transducer P23ID and an oscillation detector, respectively). An arterial blood sample $(150 \mu \mathrm{l})$ was analyzed for $\mathrm{Hb}$ concentration and oxygen saturation (OSM 2 Hemoximeter, Radiometer, Copenhagen), pH, and oxygen tension (ABL 30, Radiometer). Adjustments of ventilation, if necessary, were made. Another equally large arterial blood sample was analyzed for glucose and lactate concentrations using standard enzymatic techniques and spectrophotometric analysis $(20,21)$.

For the recording of SEP the skin over the skull was incised sagittally and retracted. Holes ( $1.0 \mathrm{~mm}$ in diameter) were drilled through the bone on both sides, great care being taken to achieve a symmetric position, $6-8 \mathrm{~mm}$ (small or big animals, respectively) from the sagittal suture and 1-2 $\mathrm{mm}$ behind the coronal suture, corresponding to the primary sensory cortex for the nose area (22). Recording electrodes (steel wire $1.0 \mathrm{~mm}$ in diameter) were placed on the dural surface. The indifferent electrode was placed behind the lambdoid suture in another hole drilled in the bone over the occipital cortex. The EEG was recorded on the Grass polygraph. A tactile stimulus was derived from a pneumatically driven mechanical stimulator (spring charged plastic rod $2.0 \mathrm{~mm}$ in diameter) applied to the nostril on the left side. Stimulus trigging and averaging of evoked potentials was accomplished by a micro-processor built for the purpose (Department of Medical Electronics, Chalmer's University of Technology, Gothenburg, Sweden). Technical specifications included amplifier bandwidth $0.5-250 \mathrm{~Hz}$ and sampling frequency $1024 \mathrm{~Hz}$. Pre-trig value (baseline) was displayed in $6 \%$ of the available printer space. Thirty-two bipolar responses (stimulus interval $2000 \mathrm{~ms}$ ) from the ipsi- and contralateral side were averaged and displayed on the printer (Seikosha GP 500A, Seikosha Company Ltd., Tokyo, Japan). This procedure produced a printout of SEP every other minute (Fig. 1). In this study the contralateral response was analyzed. Latency was measured from the onset of stimulus to the main peak of the first positive wave, the amplitude of which was measured from the basal level. This wave has been considered as a "primary response," i.e. no attempt has been made to separate subcortical and cortical components. As basal value of latency and amplitude, the mean of the five

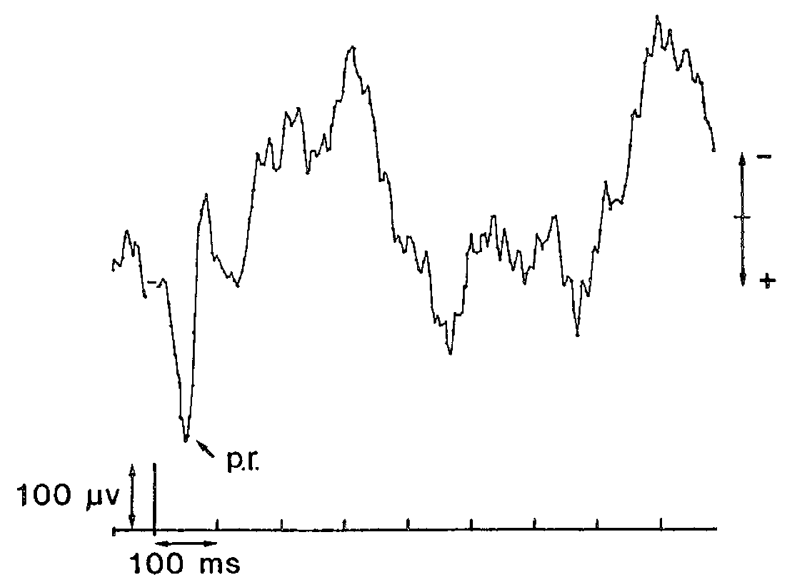

Fig. 1. Original recording of the contralateral SEP under basal conditions (normoxia). The positive deflection of the primary response (p.r.) is indicated. recordings preceding the institution of hypoxia, was calculated.

Hypoxia. When steady state was achieved (stable SEP, blood pressure, heart rate, and blood gases within normal limits; Tables 2 and 3) hypoxia was instituted in 29 animals in steps of 20 min duration and with increasing severity; nitrous oxide was kept constant at 50 or $60 \%$ and nitrogen was introduced to reduce oxygen concentration to 12,9 , and $6 \%$, respectively. After the institution of hypoxia neither stimulation nor ventilation (apart from the gas mixture) was altered.

Blood samples for determination of blood gases, glucose, and lactate concentrations were taken at the end of each 20 -min period. The SEP value corresponding to these samples was calculated as the mean of the values of the two recordings preceding the shift to the next hypoxic level. The last sample was taken when the SEP was extinguished.

Control series. Inasmuch as the amount of blood needed for the analysis $(300 \mu \mathrm{l})$ corresponds to 5 and $10 \%$ of the blood volume for the biggest and smallest animals, respectively, a control series was carried out. In 25 animals under normoxia the same amount was taken at the same intervals and the same parameters were followed. The two series will be referred to as "hypoxic" and "control," respectively.

Statistical analysis. Inasmuch as the distribution of the variables investigated did not fit the normal distribution, comparisons between groups were performed with the Wilcoxon rank sum test. A $p$ value $<0.05$ was considered significant. Linear multiple regression analysis (23) with SEP as dependent and birth weight and blood pressure as independent variables was performed.

\section{RESULTS}

The animals were divided into three groups according to birth weight: $l) \geq 101 \mathrm{~g}(n=10,12), 2) 71-100 \mathrm{~g}(n=11,10)$, and 3) $\leq 70 \mathrm{~g}(n=8,3)$ in hypoxic and control series, respectively. These groups are also referred to as appropriately grown group, moderately growth-retarded group, and severely growth-retarded group, respectively. Birth weight and length of gestation in the different groups are presented in Table 1 .

The primary response of the SEP was highly reproducible within each animal under basal conditions. The latency of the primary response under basal conditions was $56.2(46.2-71.6)$, $55.8(38.2-71.6)$, and $53.6(33.8-66.2) \mathrm{ms}$ (median and range) for group 1,2, and 3, respectively (hypoxic plus control series). When the contralateral primary response of the SEP was considered the severely growth-retarded group of animals tolerated 14 min of hypoxia (4-27) (median and range), whereas the moderately growth-retarded animals tolerated $26 \mathrm{~min}(22-45)$ and the appropriately grown animals withstood $46 \mathrm{~min}(26-74)$ before the SEP was extinguished. The differences between the groups were all significant $(p<0.01)$. The amplitude of the contralateral primary response during the whole sequence of hypoxia is shown in Figure 2. In the hypoxic series, at the first level of hypoxia

Table 1. Birth wt and gestational ages in three groups of animals in hypoxic and control series; medians and ranges

\begin{tabular}{|c|c|c|c|}
\hline Birth wt group & $\begin{array}{c}\mathrm{I} \\
\geq 101 \mathrm{~g} \\
\end{array}$ & $\begin{array}{c}\mathrm{II} \\
71-100 \mathrm{~g}\end{array}$ & $\begin{array}{c}\text { III } \\
\leq 70 \mathrm{~g} \\
\end{array}$ \\
\hline \multicolumn{4}{|l|}{ Hypoxic series } \\
\hline Birth wt (g) & $112(101-135)$ & $90(75-100)$ & $60(46-70)$ \\
\hline $\begin{array}{l}\text { Gestational age } \\
\text { (days) }\end{array}$ & $68(64-72)$ & $68(64-71)$ & $66(64-69)$ \\
\hline$n$ & 10 & 11 & 8 \\
\hline \multicolumn{4}{|l|}{ Control series } \\
\hline Birth wt (g) & $109(102-125)$ & $85(72-92)$ & $54(50-64)$ \\
\hline $\begin{array}{l}\text { Gestational age } \\
\quad \text { (days) }\end{array}$ & $67(65-69)$ & $67(67-72)$ & $66(63-70)$ \\
\hline$n$ & 12 & 10 & 3 \\
\hline
\end{tabular}


$\left(\mathrm{FIO}_{2}=12 \%\right)$ the responses in group 1 [92 (45-150)] (median and range) and group $2[58(20-128)]$ are only moderately reduced and are significantly different from that of group $3[0$ $(0-104)]$. At the second level of hypoxia $\left(\mathrm{FrO}_{2}=9 \%\right)$ the median value of group 2 becomes zero (range $0-26$ ) which is significantly different from that of group 1 [96 (0-119)]. The number of animals retaining part of their response after the first hypoxic level was $10,11,3$, and after the second $8,2,0$, for group 1,2 , and 3 , respectively. The primary response of the animals in the control series did not change significantly (Fig. 2). For groups 1, 2 , and 3 , respectively, the values were (medians and ranges) at sample 1: $91(0-275), 100(44-145), 83(38-123)$ and at sample 2: 90 (0-214), 97 (56-161), 94 (0-96). Only two animals lost their response, one in group one at the first sample and one in group three at the second sample.

To investigate the influence of birth weight and blood pressure on SEP under hypoxia, a rough model was constructed as described previously. The regression equation was: $\mathrm{SEP}=-19.5+$

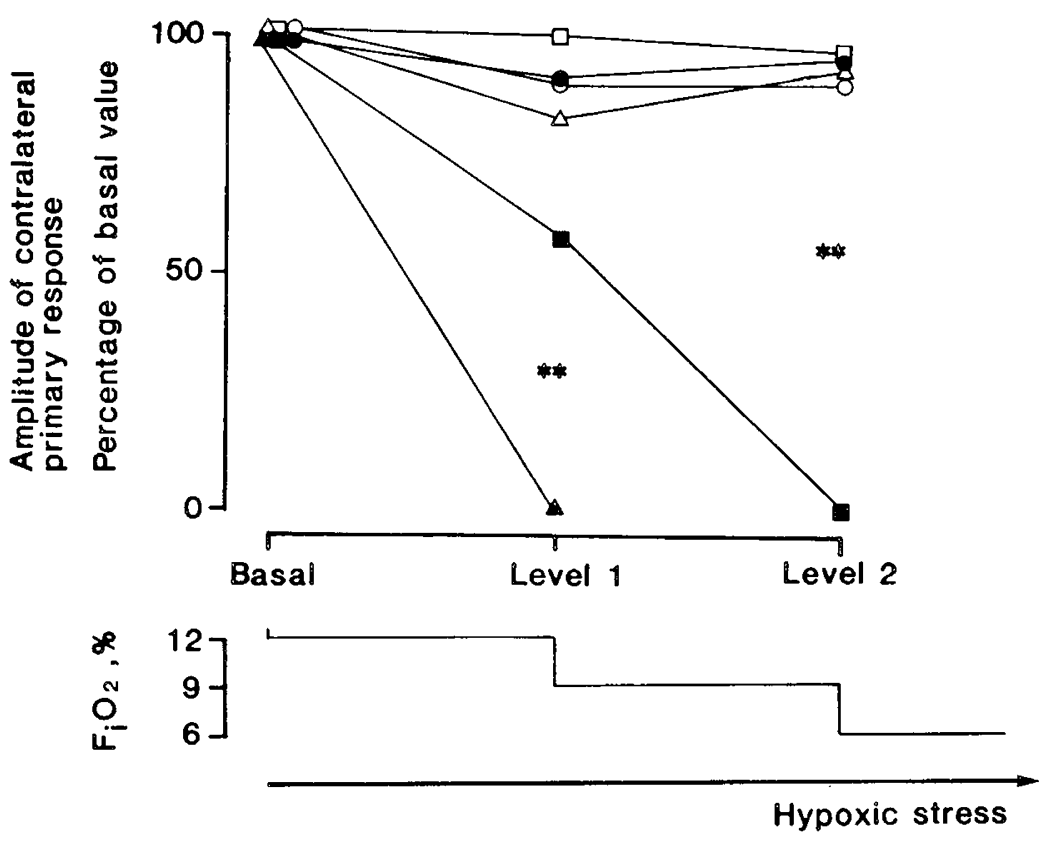

Birth weight, g Control series Hypoxic series

$\begin{array}{ccc}\geq 101 & 0 & \\ 71-100 & 0 & \Delta \\ \leq 70 & \Delta & \end{array}$

Fig. 2. Amplitude of the contralateral primary response (percentage of basal value) for the different weight groups as a function of hypoxic stress (time under hypoxia plus stepwise increased severity of hypoxia) or blood volume reduction (hypoxic and control series, respectively); median values. ${ }^{* *} p<0.01$.

Table 2. Arterial $p H, P_{a 02}$ in $k P a$ and $S_{a o 2}$ in percent for the different groups at different levels of oxygenation (hypoxic series) and at different samples (control series); medians and ranges

\begin{tabular}{|c|c|c|c|c|c|c|c|c|c|}
\hline \multirow[b]{2}{*}{ Group } & \multicolumn{3}{|c|}{ I. $\geq 101 \mathrm{~g}(n=10)$} & \multicolumn{3}{|c|}{ II. $71-100 \mathrm{~g}(n=11)$} & \multicolumn{3}{|c|}{ III. $\leq 70 \mathrm{~g}(n=8)$} \\
\hline & $\mathrm{pH}$ & $\mathrm{PO}_{2}$ & $\mathrm{SO}_{2}$ & $\mathrm{pH}$ & $\mathrm{PO}_{2}$ & $\mathrm{SO}_{2}$ & $\mathrm{pH}$ & $\mathrm{PO}_{2}$ & $\mathrm{SO}_{2}$ \\
\hline \multicolumn{10}{|l|}{$\begin{array}{l}\text { Hypoxic series } \\
\text { Oxygen level }\end{array}$} \\
\hline Basal & $\begin{array}{c}7.41 \\
(7.35-7.46)\end{array}$ & $\begin{array}{c}16.09 \\
(8.35-25.69)\end{array}$ & $\begin{array}{c}99.5 \\
(94.2-100.0)\end{array}$ & $\begin{array}{c}7.42 \\
(7.32-7.48)\end{array}$ & $\begin{array}{c}12.91 \\
(9.55-21.88)\end{array}$ & $\begin{array}{c}100.0 \\
(94.0-100.0)\end{array}$ & $\begin{array}{c}7.40 \\
(7.32-7.51)\end{array}$ & $\begin{array}{c}11.12 \\
(10.27-19.46)\end{array}$ & $\begin{array}{c}100.0 \\
(93.1-100.0)\end{array}$ \\
\hline Level 1 & 7.38 & 3.10 & 38.6 & 7.37 & 3.00 & 37.6 & 7.36 & 2.70 & 31.1 \\
\hline \multirow[t]{3}{*}{$\begin{array}{l}\text { Level } 2 \\
\left(\mathrm{~F}_{\mathrm{iO} 2}=9 \%\right)\end{array}$} & $\begin{array}{c}(1.31-7.54) \\
7.29 \\
(7.05-7.50)\end{array}$ & $\begin{array}{c}(2.56-5.34) \\
2.49 \\
(2.09-3.16)\end{array}$ & $\begin{array}{c}(36.0-53.0) \\
23.8 \\
(19.6-30.3)\end{array}$ & $\begin{array}{c}(1.21-1.41) \\
7.22 \\
(7.08-7.32)\end{array}$ & $\begin{array}{c}(2.43-3.48) \\
2.27 \\
(1.95-2.70)\end{array}$ & $\begin{array}{c}17.8 \\
17.8 \\
(12.7-30.3)\end{array}$ & & & \\
\hline & \multicolumn{3}{|c|}{$\mathrm{I} . \geq 101 \mathrm{~g}(n=12)$} & \multicolumn{3}{|c|}{ II. $71-100 \mathrm{~g}(n=10)$} & \multicolumn{3}{|c|}{ III. $\leq 70 \mathrm{~g}(n=3)$} \\
\hline & $\mathrm{pH}$ & $\mathrm{PO}_{2}$ & $\mathrm{SO}_{2}$ & $\mathrm{pH}$ & $\mathrm{PO}_{2}$ & $\mathrm{SO}_{2}$ & $\mathrm{pH}$ & $\mathrm{PO}_{2}$ & $\mathrm{SO}_{2}$ \\
\hline \multicolumn{10}{|l|}{ Control series } \\
\hline Basal & $\begin{array}{c}7.34^{* 2} \\
(7.31-7.48)\end{array}$ & $\begin{array}{c}22.04 \\
(10.74-33.21)\end{array}$ & $\begin{array}{c}100.0 \\
(93.1-100.0)\end{array}$ & $\begin{array}{c}7.46 \\
(7.35-7.52)\end{array}$ & $\begin{array}{c}18.06 \\
(7.18-32.97)\end{array}$ & $\begin{array}{c}100.0 \\
(90.7-100.0)\end{array}$ & $\begin{array}{c}7.56 \\
(7.39-7.56)\end{array}$ & $\begin{array}{c}19.76 \\
(19.53-25.81)\end{array}$ & $\begin{array}{c}100.0 \\
(95.9-100.0)\end{array}$ \\
\hline Sample 1 & $\begin{array}{c}7.37 \\
(7.21-7.43)\end{array}$ & $\begin{array}{c}17.20 \\
(8.29-24.29)\end{array}$ & $\begin{array}{c}100.0 \\
(91.7-100.0)\end{array}$ & $\begin{array}{c}7.38 \\
(7.27-7.44)\end{array}$ & $\begin{array}{c}17.44 \\
(7.85-26.15)\end{array}$ & $\begin{array}{c}100.0 \\
(90.0-100.0)\end{array}$ & $\begin{array}{c}7.36 \\
(7.31-7.45)\end{array}$ & $\begin{array}{c}8.75 \\
(4.96-13.49)\end{array}$ & $\begin{array}{c}94.8 \\
(60.2-100.0)\end{array}$ \\
\hline Sample 3 & $\begin{array}{c}7.25 \\
(6.99-7.39)\end{array}$ & $\begin{array}{c}16.83 \\
(2.07-21.15)\end{array}$ & $\begin{array}{c}100.0 \\
(14.4-100.0)\end{array}$ & $\begin{array}{c}7.26 \\
(7.19-7.33)\end{array}$ & $\begin{array}{c}13.65 \\
(8.18-21.83)\end{array}$ & $\begin{array}{c}98.0 \\
(89.6-100.0)\end{array}$ & $\begin{array}{c}7.22 \\
(7.17-7.26)\end{array}$ & $\begin{array}{c}19.75 \\
(19.22-20.28)\end{array}$ & $\begin{array}{c}75.8 \\
(49.4-100.0) \\
\end{array}$ \\
\hline
\end{tabular}

* Significant differences between groups at each oxygen level or at different samples, $p<0.05$. The number after the asterisk indicates the group to which the difference is significant. 
Table 3. Mean arterial blood pressure (MAP) in $\mathrm{mm} \mathrm{Hg}$, heart rate (HR) in beats/min, $\mathrm{Hb}$ in $\mathrm{g} /$ liter, glucose and lactate concentrations, in mmol/liter, for the different groups at different levels of oxygenation (hypoxic series) and at different samples (control series); medians and ranges

\begin{tabular}{|c|c|c|c|c|c|c|c|c|c|c|c|c|c|c|c|}
\hline \multirow[b]{2}{*}{ Group } & \multicolumn{5}{|c|}{ I. $\geq 101 \mathrm{~g}(n=10)$} & \multicolumn{5}{|c|}{ II. $71-100 \mathrm{~g}(n=11)$} & \multicolumn{5}{|c|}{ III. $\leq 70 \mathrm{~g}(n=8)$} \\
\hline & MAP & HR & $\mathrm{Hb}$ & Glucose & Lactate & MAP & $\mathrm{HR}$ & $\mathrm{Hb}$ & Glucose & Lactate & MAP & HR & $\mathrm{Hb}$ & Glucose & Lactate \\
\hline \multicolumn{16}{|l|}{ Hypoxic series } \\
\hline \multicolumn{16}{|l|}{ Oxygen level } \\
\hline Basal & $\begin{array}{c}36^{* 3} \\
(28-50)\end{array}$ & $\begin{array}{l}288^{* 3} \\
(230-310)\end{array}$ & $\begin{array}{c}137^{* * * 3} \\
(116-157)\end{array}$ & $\begin{array}{l}5.48 \\
(1.03- \\
6.83)\end{array}$ & $\begin{array}{c}1.14 \\
(0.38-2.31)\end{array}$ & $\begin{array}{c}42^{* 3} \\
(24-51)\end{array}$ & $\begin{array}{c}260 \\
(230-385)\end{array}$ & $\begin{array}{c}146^{* 3} \\
(115- \\
162)\end{array}$ & $\begin{array}{c}5.43 \\
(3.99-9.74)\end{array}$ & $\begin{array}{c}1.84 \\
(1.01- \\
2.49)\end{array}$ & $\begin{array}{c}28 \\
(20-42)\end{array}$ & $\begin{array}{c}245 \\
(215-300)\end{array}$ & $\begin{array}{c}161 \\
(150-173)\end{array}$ & $\begin{array}{c}4.89 \\
(1.59-10.05)\end{array}$ & $\begin{array}{c}1.49 \\
(1.01-2.66)\end{array}$ \\
\hline $\begin{array}{l}\text { Level } 1 \\
\left(\mathrm{~F}_{\mathrm{io} 2}=12 \%\right)\end{array}$ & $\begin{array}{c}26^{* * 3} \\
(17-34)\end{array}$ & $\begin{array}{l}275 \\
(225-290)\end{array}$ & $\begin{array}{l}133 \\
(123-160)\end{array}$ & $\begin{array}{c}5.87^{* 2,3} \\
(1.80- \\
14.78)\end{array}$ & $\begin{array}{c}2.26^{* 3} \\
(1.56-4.92)\end{array}$ & $\begin{array}{c}25^{* * 3} \\
(12-43)\end{array}$ & $\begin{array}{c}275 \\
(225-405)\end{array}$ & $\begin{array}{l}148 \\
(115- \\
171)\end{array}$ & $\begin{array}{c}8.77 \\
(4.83-14.45)\end{array}$ & $\begin{array}{c}3.06 \\
(1.76-7.23)\end{array}$ & $\begin{array}{c}16 \\
(8-27)\end{array}$ & $\begin{array}{c}245 \\
(185-340)\end{array}$ & $\begin{array}{c}165 \\
(147-173)\end{array}$ & $\begin{array}{c}10.12 \\
(2.72-15.48)\end{array}$ & $\begin{array}{c}6.04 \\
(1.92-10.30)\end{array}$ \\
\hline \multirow[t]{3}{*}{$\begin{array}{l}\text { Level } 2 \\
\left(\mathrm{~F}_{\mathrm{io} 2}=9 \%\right)\end{array}$} & $\begin{array}{l}20 \\
(9-26)\end{array}$ & $\begin{array}{l}253 \\
(185-275)\end{array}$ & $\begin{array}{l}143 \\
(126-159)\end{array}$ & $\begin{array}{l}4.78 \\
(1.11- \\
19.42)\end{array}$ & $\begin{array}{c}8.11 \\
(4.40-10.99)\end{array}$ & $\begin{array}{l}20 \\
(5-32)\end{array}$ & $\begin{array}{c}252 \\
(148-390)\end{array}$ & $\begin{array}{c}148 \\
S(118- \\
176)\end{array}$ & $\begin{array}{c}11.35 \\
(4.69-22.38)\end{array}$ & $\begin{array}{c}9.28 \\
(6.12-12.11)\end{array}$ & & & & & \\
\hline & \multicolumn{5}{|c|}{ I. $\geq 101 \mathrm{~g}(n=12)$} & \multicolumn{5}{|c|}{ II. $71-100 \mathrm{~g}(n=10)$} & \multicolumn{5}{|c|}{ III. $\leq 70 \mathrm{~g}(n=3)$} \\
\hline & MAP & HR & $\mathrm{Hb}$ & Glucose & Lactate & MAP & HR & $\mathrm{Hb}$ & Glucose & Lactate & MAP & HR & $\mathrm{Hb}$ & Glucose & Lactate \\
\hline \multicolumn{16}{|c|}{ ( } \\
\hline Basal & $\begin{array}{c}41^{* 2,3} \\
(32-52)\end{array}$ & $\begin{array}{c}280^{* 2,3} \\
(235-310)\end{array}$ & $\begin{array}{l}138 \\
(113-160)\end{array}$ & $\begin{array}{l}5.96 \\
(3.24- \\
15.00)\end{array}$ & $\begin{array}{c}1.88 \\
(0.84-4.70)\end{array}$ & $\begin{array}{c}35 \\
(22-44)\end{array}$ & $\begin{array}{c}240 \\
(220-285)\end{array}$ & $\begin{array}{c}162 \\
(106-171)\end{array}$ & $\begin{array}{c}4.68 \\
(2.76-9.95)\end{array}$ & $\begin{array}{c}1.86 \\
(0.83-4.86)\end{array}$ & $\begin{array}{c}34 \\
(30-35)\end{array}$ & $\begin{array}{c}225 \\
(210-230)\end{array}$ & $\begin{array}{c}142 \\
(142-170)\end{array}$ & $\begin{array}{c}5.07 \\
(3.34-5.56)\end{array}$ & $\begin{array}{c}1.96 \\
(1.43-2.87)\end{array}$ \\
\hline Sample 1 & $\begin{array}{c}39^{* 2} \\
(22-66)\end{array}$ & $\begin{array}{c}310^{* * 2,3} \\
(270-410)\end{array}$ & $\begin{array}{c}136 \\
(116-154)\end{array}$ & $\begin{array}{l}7.02 \\
(3.08- \\
13.63)\end{array}$ & $\begin{array}{c}1.74 \\
(0.99-6.65)\end{array}$ & $\begin{array}{l}27 \\
(17-44)\end{array}$ & $\begin{array}{c}270 \\
(230-280)\end{array}$ & $\begin{array}{c}149 \\
(90-171)\end{array}$ & $\begin{array}{c}4.80 \\
(2.60-11.95)\end{array}$ & $\begin{array}{c}2.28 \\
(1.17-5.22)\end{array}$ & $\begin{array}{c}28 \\
(13-30)\end{array}$ & $\begin{array}{c}260 \\
(215-265)\end{array}$ & $\begin{array}{c}148 \\
(124-177)\end{array}$ & $\begin{array}{c}5.74 \\
(2.98-8.20)\end{array}$ & $\begin{array}{c}3.12 \\
(1.22-6.78)\end{array}$ \\
\hline Sample 2 & $\begin{array}{l}40 \\
(5-45)\end{array}$ & $\begin{array}{l}310 \\
(80-430)\end{array}$ & $\begin{array}{l}131 \\
(114-170)\end{array}$ & $\begin{array}{l}7.27 \\
(5.26- \\
16.20) \\
\end{array}$ & $\begin{array}{c}2.02 \\
(1.27-8.90)\end{array}$ & $\begin{array}{c}22 \\
(11-43)\end{array}$ & $\begin{array}{c}280 \\
(225-350)\end{array}$ & $\begin{array}{c}152 \\
(88-167)\end{array}$ & $\begin{array}{c}5.82 \\
(3.17-21.80)\end{array}$ & $\begin{array}{c}4.71 \\
(1.46-9.95)\end{array}$ & 12 & $\begin{array}{c}280 \\
(230-330)\end{array}$ & $\begin{array}{c}130 \\
(112-149)\end{array}$ & 3.03 & 1.51 \\
\hline
\end{tabular}

Significant differences between groups at each oxygen level or at different samples: ${ }^{*} p<0.05,{ }^{* *} p<0.01,{ }^{* * *} p<0.001$. The number after asterisks indicates the group to which the difference is significant. 
1.10 . birth weight -0.67 mean arterial blood pressure. The SE of the coefficient of birth weight was 0.33 with a $p$ value $<0.01$. For blood pressure the corresponding values were 1.12 and nonsignificant, respectively. The $R^{2}$ value was $26.9 \%$.

Arterial blood $\mathrm{pH}$, oxygen tension, and oxygen saturation in the different groups of the two series are given in Table 2. No statistically significant differences in blood gases or $\mathrm{pH}$ between the groups were found in the hypoxic series. In the control series at basal conditions group 1 had slightly lower pH than group 2 . In the hypoxic series at level $1 \mathrm{PaO}_{2}$ and $\mathrm{SaO}_{2}$ was reduced in each group compared to basal conditions whereas no change of $\mathrm{pH}$ took place in either group. At level 2 all three parameters were reduced. In the control series $\mathrm{pH}$ and $\mathrm{PaO}_{2}$ fell slightly in all groups whereas $\mathrm{SaO}_{2}$ remained constant except for in group 3 where it fell.

Mean arterial blood pressures, heart rates, $\mathrm{Hb}$ concentrations, arterial glucose, and lactate values are displayed in Table 3. In the hypoxic series at the basal level (normoxia) the severely growth-retarded group had higher $\mathrm{Hb}$ concentration and lower arterial blood pressure than the other groups. It also had lower heart rate than the appropriately grown group. In the control series the moderately and severely growth-retarded groups both had lower blood pressure and heart rate than the appropriately grown group. In the hypoxic series, at level 1 group 3 had lower blood pressures than the other groups. Group 1 had lower glucose concentration than the other groups and lower lactate levels than group 3. In the control series, at sample 1, group 1 had higher blood pressure than group 2 and higher heart rate than the other groups. At level 2/sample 2 no significant differences between the groups were present in either series.

\section{DISCUSSION}

Growth-retarded newborn guinea pigs demonstrated a decreased tolerance of hypoxia when time to complete loss of SEP was considered and when the amplitude of the contralateral primary response was evaluated (Fig. 2). Moreover, a relationship was obtained between degree of growth retardation and reduction of hypoxia tolerance. It should be noted that both these modes of assessing tolerance of hypoxia underestimate the difference between the groups, because in estimating the time until loss of SEP, account must be taken of the fact that the degree of hypoxia was increased at each 20 -min period, i.e. the hypoxic stress per time unit was gradually increased. Furthermore, some animals will lose their SEP before the completion of a hypoxic level ( 20 min). This means that sample 1 will be drawn earlier for group 3 than for group 1 and 2 and sample 2 earlier for group 2 than for group 1. Thus, at each sample bigger animals have been subjected to a more severe hypoxic stress than smaller animals. The animals in the control series did not respond with a reduction of the amplitude. Thus, the blood sampling procedure per se, inducing a relatively more pronounced blood loss in the growthretarded animals, cannot explain the over all changes or the group differences taking place in the hypoxic series.

Similar changes of blood gases and $\mathrm{pH}$ took place in all groups in the hypoxic series (Table 2). In the control series only minor alterations were seen. Metabolically, hypoxic animals showed increases of glucose and lactate concentrations in proportion to the degree of hypoxic stress and to the degree of growth retardation (Table 3). This might be attributed to an increased mobilization of catecholamines in the growth-retarded animals (24). Possibly, this could put growth-retarded animals at an advantage due to increased availability of energy-rich substrates. The control animals exhibited slight changes only. In the hypoxic series mean arterial blood pressure under normoxia and hypoxia and heart rate under normoxia were lower in the severely growthretarded animals (Table 3). Similar differences have been reported from growth-retarded guinea pig fetuses (10) indicating that this is part of the pathophysiology in IUGR.

The guinea pig is at birth more mature in terms of cerebral development than man. This applies to morphologic, electro- physiologic, and behavioral aspects (25). In man asymmetric growth retardation is thought to develop late in pregnancy (16). In this respect the model used complies well with the human situation (26).

Evoked potentials have been used to detect and quantify changes during hypoxia (27-29) and in growth-retarded infants $(11,12)$. We used the amplitude of the contralateral primary response as the measure of functional cerebral integrity. The major part of this response consists of activity in the somatosensory cortex but contributions are made from structures in the afferent pathway (30). These components cannot be separated in our recordings. Inasmuch as the activity from relay stations is likely to be more resistant to hypoxia, this will constitute an increasing but quantitatively unknown part of the response as the experiment is proceeding. Under the assumption that this successive change is not systematically different between appropriately grown and growth-retarded animals, this does not invalidate our results. Because of these considerations, latency values have only been calculated from recordings under normoxia.

Growth-retarded guinea pig fetuses have a reduced $\mathrm{CMRO}_{2}$ (10). This could reflect an adaption to the process of growth retardation which is also indicated by the ability of the growthretarded human fetus and neonate to adapt its circulation favoring the brain (31). SEP has been shown to closely reflect $\mathrm{CMRO}_{2}$ in hypoxic hypoxia $(28,29)$. When multiple regression analysis was applied the SEP response to hypoxia was shown to be dependent on weight but not on blood pressure. From these observations it seems likely that the observed changes in SEP amplitude reflect differences in intracerebral mechanisms between the weight groups rather than a difference in cerebral perfusion.

Uterine artery ligation in midgestation in the guinea pig and late gestation in the rat induces an asymmetric growth retardation $(10,32,33)$. In the rat, long-lasting alterations in the CNS have been shown such as reduced myelination (34), modified fatty acid composition of neurons and oligodendrocytes (35), altered serotonin metabolism with increased levels (33), and disturbed thymidine and DNA metabolism (36). However, levels of oxidative metabolites were not changed (37). In comparisons of SGA and AGA fetuses and infants a complex picture has emerged with indications of both delayed and accelerated central nervous maturation: delayed appearance of fetal "behavioral states" (15), reduced amount and changed quality of fetal movements (14) and earlier appearance of mature breathing pattern (38) and decreased latency of brainstem auditory evoked responses (12). Combined with these alterations is an increased morbidity and mortality both in the short (5-7) and long term (1-4).

Perinatal hypoxia inhibits cerebral monoamine synthesis in the rat, a change that increases survival time under anoxia. After an hypoxic episode, an increased availability of monoamine precursors and an increased rate of monoamine synthesis prevails (39). This suggests that in growth-retarded individuals the intrauterine hypoxia will reduce the activity of the highly hypoxiasensitive, rate-limiting enzymes of monoamine synthesis (40) and slow the cerebral metabolic rate (10). The trophic influences of monoamines, particularly serotonin, on cerebral growth (41) will be diminished and cerebral growth retardation will result. In the neonatal period concentrations of monoamines, particularly of serotonin, are increased in the brains of growth-retarded rats. This has been interpreted as a compensatory mechanism (33). Thus, it is possible that a highly active CNS of the growthretarded neonate will be sensitive to adverse influences, e.g. a reduced oxygen availability.

The results of this study indicate that there is a reduced perinatal cerebral tolerance of hypoxia in growth-retarded individuals which can be explained by a change in the brain itself. A relation is suggested between the degree of growth retardation and the reduction of hypoxia tolerance. This is in line with the findings of suboptimal long-term mental development in mildly growth retarded infants $(-2 \mathrm{SD}<$ birth weight $\leq 1$ SD) (42). These findings indicate that, in the clinical situation, fetuses and 
neonates with a minor degree of growth retardation may have a decreased ability to withstand oxygen lack.

\section{REFERENCES}

1. Hagberg G, Hagberg B, Olow I 1976 The changing panorama of cerebral palsy in Sweden 1954-1970. III. The importance of foetal deprivation of supply. Acta Paediatr Scand 65:403-408

2. Sabel KG, Olegård R, Victorin L 1976 Remaining sequelae with modern perinatal care. Pediatrics 57:652-658

3. Calame A, Fawer CL, Claeys V, Arrazola L, Ducret S, Jaunin L 1986 Neurodevelopmental outcome and school performance of very-low-birthweight infants at 8 years of age. Eur J Pediatr 145:461-466

4. Rantakallio P 1985 A 14-year follow-up of children with normal and abnormal birth weight for their gestational age. A population study. Acta Paediatr Scand 74:62-69

5. Holmqvist $P$, Ingemarsson $E$, Ingemarsson I 1986 Intrauterine growth retardation and gestational age. Acta Obstet Gynecol Scand 65:633-638

6. Ounsted M, Ounsted C 1973 On fetal growth rate (its variations and their consequences). Clin Dev Med 46:83-99

7. Low JA, Poncham SR, Worthington D 1976 Fetal heart deceleration patterns in relation to asphyxia and weight-gestational age percentile of the fetus. Obstet Gynecol 47:14-20

8. Olegård R, Gustafson A, Kjellmer I, Victorin L 1975 Nutrition in low-birthweight infants: III. Lipolysis and FFA elimination after intravenous administration of fat emulsion. Acta Paediatr Scand 64:745-751

9. Williams PR, Fiser RH, Sperling MA, Oh W 1975 Effects of oral alanine on blood glucose, plasma glucagon and insulin concentrations in small-forgestational-age infants. N Engl J Med 292:612-614

10. Carter AM, Gu W 1988 Cerebral blood flow and fetal oxygenation in the growth retarded guinea pig fetus. In: Jones CT (ed) Fetal and Neonatal Development. Perinatology Press, Ithaca, NY, pp 86-89

11. Hrbek A, Iversen K, Olsson T 1982 Evaluation of cerebral function in newborn infants with fetal growth retardation. In: Courjon J, Mauguiere F, Revol M (eds) Clinical Applications of Evoked Potentials in Neurology. Raven Press, New York, pp 89-95

12. Pettigrew AG, Edwards DA, Henderson-Smart DJ 1985 The influence of intrauterine growth retardation on brainstem development of preterm infants. Dev Med Child Neurol 27:467-472

13. Visser GHA 1984 Antenatal cardiotocography in the evaluation of fetal wellbeing. Aust NZ J Obstet Gynaecol 24:80-85

14. Bekedam DJ, Visser GHA, deVries JJ, Prechtl HFR 1985 Motor behaviour in the growth retarded fetus. Early Hum Dev 12:155-165

15. Van Vliet MAT, Martin CB Jr, Nijhuis JG, Prechtl HFR 1985 Behavioural states in growth-retarded human fetuses. Early Hum Dev 12:183-197

16. Chiswick ML 1985 Intrauterine growth retardation. Brit Med J 291:845-848

17. Elvidge $H 1972$ Production of dated pregnant guinea-pigs without post-partum matings. J Inst Anim Technol 23:111-117

18. Wigglesworth JS 1964 Experimental growth retardation in the foetal rat. J Pathol Bacteriol 88:1-13

19. Mårtensson L 1984 The pregnant rabbit, guinea pig, sheep and rhesus monkey as models in reproductive physiology. Eur J Obstet Gynecol Reprod Biol 18:169-182

20. Schmidt FH 1973 Enzymatische teste zur schnelldiagnose. 567-568 3 Internationales Donau-Symposium über Diabetes mellitus. W. Maudrich WienMünchen-Bern (modified according to Boehringer-Mannheim)
21. Gawehn K 1984 D-Lactate. In: Bergmeyer HU (ed) Methods of Enzymatic Analysis, 3rd ed, vol. vi. Verlag Chimie, Weinheim, pp 588-592

22. Zeigler HP 1964 Cortical sensory and motor areas of the guinea pig ("Cavia porcellus"). Arch Ital Biol 102:587-598

23. Sokal RR, Rohlf FJ 1981 Biometry, 2nd ed. WH Freeman and Company, New York, pp 617-641

24. Jones CT, Robinson JS 1983 Studies on experimental growth retardation in sheep. Plasma catecholamines in fetuses with small placenta. J Dev Physiol 5:77-87

25. Himwich WA (ed) 1970 Developmental Neurobiology. Charles C Thomas, Springfield, IL

26. Jansson T, Thordstein M, Kjellmer I 1986 Placental blood flow and fetal weight following uterine artery ligation. Temporal aspects of intrauterine growth retardation in the guinea pig. Biol Neonate 49:172-180

27. Manil J, Colin F, Bourgain RH 1978 Modifications of somatosensory evoked cortical potentials during hypoxia in the awake rabbit. Adv Exp Med Biol 94:509-516

28. McPherson RW, Zeger S, Traystman RJ 1986 Relationship of somatosensory evoked potentials and cerebral oxygen consumption during hypoxic hypoxia in dogs. Stroke 17:30-36

29. McPherson RW, Eimerl D, Traystman RJ 1987 Interaction of hypoxia and hypercapnia on cerebral hemodynamics and brain electric activity in dogs. Am J Physiol 253:H890-H897

30. Wiederholt WC, Iragui-Madoz VJ 1977 Far field somatosensory potentials in the rat. Electroencephalogr Clin Neurophysiol 42:456-465

31. Wladimiroff J, van Bel F 1987 Fetal and neonatal cerebral blood flow. Semin Perinatol 11:335-346

32. Lafeber HN, Rolph TP, Jones CT 1984 Studies on the growth of the fetal guinea pig. The effects of ligation of the uterine artery on organ growth and development. J Dev Physiol 6:441-459

33. Chanez C, Priam M, Flexor MA, Hamon M, Bourgoin S, Kordon C, Minkowski A 1981 Long lasting effects of intrauterine growth retardation on 5HT metabolism in the brain of developing rats. Brain Res 207:397-408

34. Bourre JM, Morand O, Chanez C, Dumont O, Flexor MA 1981 Influence of intrauterine malnutrition on brain development: alteration of myelination. Biol Neonate 39:96-99

35. Morand O, Chanez C, Masson M, Dumont O, Flexor MA, Baumann N, Bourre JM 1981 Intrauterine growth retardation (malnutrition by vascular ligation) induces modifications in fatty acid composition of neurons and oligodendrocytes. J Neurochem 37:1057-1060

36. Chanez C, Privat A, Flexor MA, Drian J 1985 Effect of intrauterine growth retardation on developmental changes in DNA and $\left({ }^{14} \mathrm{C}\right)$ thymidine metabolism in different regions of rat brain: histological and biochemical correlations. Brain Res 21:283-292

37. Brown JD. Vannucci RC 1978 Cerebral oxidative metabolism during intrauterine growth retardation. Biol Neonate $34: 170-173$

38. Dornan JC, Ritchie JWK, Ruff S 1984 The rate and regularity of breathing movements in the normal and growth-retarded fetus. Br J Obstet Gynaecol $91: 31-36$

39. Hedner T 1978 Central monoamine metabolism and neonatal oxygen deprivation. Acta Physiol Scand [Suppl] 460:1-34

40. Davis JN, Carlsson A, MacMillan V, Siesjö BK 1973 Brain tryptophan hydroxylation: dependence on arterial oxygen tension. Science 182:72-74

41. Hole K 1972 Reduced 5-hydroxyindole synthesis reduces postnatal brain growth in rats. Eur J Pharmacol 18:361-366

42. Leijon I, Billström G, Lind J 1987 Psychomotor development of children following intrauterine growth retardation. An 8-year follow-up. IXth Nordic Congress of Perinatal Medicine, 17:38 (abstr 17) 